\title{
THE IMPLICATIONS OF GUARDED NEIGHBORHOOD ON HOUSING PRICES IN URBAN MALAYSIA
}

\author{
Peter Aning Tedong ${ }^{* *}$ and Zafirah Al Sadat Zyed ${ }^{2}$ \\ ${ }^{1,2}$ Centre for Sustainable Urban Planning and Real Estate, Faculty of Built Environment, Universiti Malaya, \\ 50603 Kuala Lumpur, Malaysia \\ ${ }^{1}$ Department of Urban and Regional Planning, Faculty of Built Environment, Universiti Malaya \\ 50603 Kuala Lumpur \\ ${ }^{2}$ Department of Real Estate, Faculty of Built Environment, Universiti Malaya, 50603 Kuala \\ Lumpur
}

E-mail: * peteraning@um.edu.my

\begin{abstract}
The research on gated communities has drawn considerable attention over the last three decades as researchers identify why certain social groups of people choose to live in a fortified neighborhood. Many scholars ranging from urban geographers, urban planning, anthropologist, urban economists, sociologists to urban politics have attempted to explore the reasons behind the proliferation of gated communities throughout the world. However, less research talked about the impacts of enclosure developments on housing prices, especially in developing countries like Malaysia. Therefore, this article will examine the various actors' perceptions of guarded neighborhoods' implications towards housing prices in urban Malaysia. This article found that various actors interviewed believe that guarded neighborhoods can improve the housing prices in Malaysia. This article contributes to the general understanding of Malaysia's guarded neighborhood and has multiple implications in terms of housing prices in enclosure developments.
\end{abstract}

Keywords: Guarded Neighborhood, Perceptions, Property Prices, Malaysia

\section{INTRODUCTION}

Despite the abundance of research on gated communities (Leish, 2002; Atkinson and Blandy, 2006; Blakely, 2007; LeGoix and Webster, 2008; Vesselinov, 2012), the characteristics of these kinds of communities around the world differ from country to country. Closer to modern times, gated community has been observed to have appeared in many countries, and inevitable generated much interest and concern in the communities, particularly on the issues of security and safety (Low 2001; Le Goix 2005; Vesselinov et al., 2007; Bagaeen and Uduku, 2010). While previous research has explored the reason for gating (Blakely and Synder, 1997; Caldeira, 2000), the role of government in producing enclosures (Blakely and Snyder, 1997; Glasze,2006; Pow, 2011), and the historical context of gated communities enclosure (Bagaeen and Uduku, 2010), the property prices implications of this kind of developments are still undocumented.

Many researchers have documented that the rise of gated communities originated in the USA (Blakely and Synder, 1997; Caldeira, 2000), where at one point it has been perceived as one of the fastest-growing types of residential development in the USA (Low, 2003; Nelson, 2005; McKenzie, 2006). Beginning in the 1960s, masterplanned developments involving restricted access communities first took shape in the form of retirement communities. A majority of these communities were built in Florida, California, Texas, and Arizona (Low 2003). However, these early-gated communities were primarily designed for and aimed at wealthy senior citizens and retirees (Blakely and Synder, 1997; Low, 2003). Later in the early 1970s, the development of gated communities started to attract those from the upper-middle class. Low (2003) contended that the number of urban residents living in enclosure developments in the USA had increased drastically from 1995 to 1998 . From four million urban residents living in 
gated communities in 1995, the figure increases to eight million urban residents in 1997 before reaching sixteen million in 1998. Furthermore, the number of self-managed neighborhoods in that country has increased significantly within a span of 50 years (Nelson, 2005; Glasze, 2006). Recently, McKenzie (2011) estimated that 60 million USA populations live in privately governed neighborhoods.

Despite the abundance of literature discussing the phenomenon is revolving around enclosure developments in the USA, the increasing trend of gated communities also evidenced in other regions in the world. Among these regions in the world, it has been documented that gated communities have appeared in Latin America (Coy and Pohler, 2002; Borsdorf and Hidalgo 2010), parts of the Middle East (Glasze, 2006; Guze and Ozkan, 2010), North America, (Walks, 2006; Rosen and Grant, 2011), and Europe (Raposo, 2006; Blandy, 2006; Candan and Kolluoglu, 2009). As this research focuses on the Southeast Asia region, it was found that some real estate markets started showing an increase in gated communities, for example, in Singapore (Pow, 2011), Indonesia (Leisch, 2002; Hishiyama, 2010), Vietnam, (Huong and Sajor, 2009) and Thailand (Dick and Rimmer, 2000).

Describing Asian Cities, Miao (2003) and Pow (2007) documented the rise of gated communities in China. However, less evidence was found in Malaysia. Some researchers have attempted to examine the motivation factors living in gated communities (Misnan et al., 2010; Tedong et al., 2014); meanwhile, other researchers review the legality to enclose public spaces (Xavier, 2008; Tahir et al., 2009). This study finds less written about the implications of guarded neighborhoods towards housing prices. Therefore, this study will explore the significant implication of guarded neighborhoods toward housing prices in urban Malaysia.

\section{LITERATURE REVIEW}

\subsection{Gated communities and Marketing Strategies}

Existing literature has shown that the development of gated communities revolves around an effective marketing strategy in attracting consumers to buy new homes in urban fringe areas or infill projects in nations where security needs are prevalent, and income discrepancies are increasing. The perception that gating increases property values appears to be validated by several studies (Townshend, 2002; LeGoix, 2005; LaCour-Litte and Malpezzi, 2009). Gates and walls are intended to create and maintain the stability of property value as Blakely and Snyder (1997, p. 155) explained:

"The growing fear the loss of housing value is recasting land use planning tools and giving rise to a new surge of land management efforts aimed at retarding population growth and maintaining high land and housing price."

It was inferred that more excellent stability in property value is brought forward by having greater control over a neighborhood (Ajibola et al., 2011). Private developers and landlords see gated communities as a type of property investment (Manzi and Bowers, 2005; Csizmady, 2011). There is a robust perception where gated communities can boost and sustain property value where many residents and real estate players believe they do have a positive impact (Blakely and Snyder, 1997). Within such a broad interpretation of economic benefits, gated communities become an instrument that can conserve values from the effect of changes in a city and a way to advertise a property as being more exclusive (Gooblar, 2002; Levent and Gulumser, 2007). The aspect of better amenities and facilities was also reflected in the higher value of property in gated communities.

In addition, gated communities have also become a competent way for policymakers to protect real property values over time. For example, there was a clear difference between the properties within gated communities in California compared to properties in open neighborhoods (Le Goix and Vesselinov 2012). LaCour-Little and Malpezzi (2001) showed how over 20 years from 1979 to 1998, in St. Louis, Missouri in the USA, houses within gated areas regulate a price premium of $26 \%$ compared to houses located at unregulated streets. Gated communities have linked the dogma of privatization as corporate or private governance is more compelling than public administration, with residents more prone to pay the "subscription fee" in return to the service provisions provided by the private actors (McKenzie, 2006; Raposo, 2006). Residents perceived that services provided by the private actors could help maintain the property value in the development of gated communities.

The economic benefits of gated communities have been documented in several countries. In their study, Clement and Grant (2012) illustrated how in Barbados, gated communities permit developers to safeguard their investment from vandalism and other liability issues. Wu (2010) documented how the developer uses gated 
communities as a marketing tool, promoting gated communities as a vibrant community in a case study of China. Among the most common marketing techniques used is the developers' use of the term "luxury homes" and touting many "services and amenities" catered to the customers' needs.

Developers saw gated communities as an essential marketing strategy in the competitive real estate market. Since gated communities provide beautiful amenities and facilities and secured communities, gating may increase the property's value (Grant and Mitelsteadt, 2004). Blakely and Snyder (1997) explained that in the USA market, demand for enclosure results in a great demand for new-gated communities throughout the country. Cizmeci and Ercan (2010) gave evidence on how developers in Istanbul also use gated communities as a marketing tool to sell its housing development by promoting a privileged lifestyle for its residents.

Zooming into the local level, some local governments support enclosure developments due to their conclusive improvement to the local tax base. It has been pointed out by Le Goix (2005) how local governments tend to favor land use in the form of gated communities' development in paying the cost of urban sprawl. Similarly, McKenzie (2006) emphasized the role of local governments in promoting gated communities. He explained that local governments aspire to pursue growth and, at the same time, raise tax revenues with nominal public spending. In Maputo, South Africa, the local authorities rely on private actors to rapidly provide world-class modern infrastructure and services through the development of gated communities (Morange et al., 2012).

Sabatini and Salcedo (2007) argued that gated communities have positive economic consequences on the location of the municipalities. This is because they can improve the local economy, particularly in creating more jobs and increasing tax revenues for the local government. McKenzie (2006) and Libertun (2006) claimed that the rise of gated communities could significantly grow the urban economy and bring new investment to the surrounding suburban municipalities. Morange et al. (2012) and Damstra (2001) also noted how the state and local government favor gated communities because the cost of urban development is borne by the developers who pay for the construction of the housing infrastructure, which the cost is then passed on further to the homebuyers.

\subsection{Gated Communities Phenomenon in Malaysia}

The rise of enclosed communities in Malaysia has always been suggested to be associated with the crime rate problem in a particular residential area. However, previous research on gated communities and guarded neighborhoods in the country discuss safety and security elements without looking into the actual crime rates but rather on the total number of reported crimes (Tedong et al., 2014). Sakip et al. (2013) recognize that the residents of the private neighborhood have an enormous fear of crime than other gated communities. Mohit and Abdulla (2011) have conducted a comparative survey between 50 residents of gated communities and non-gated communities. The findings discovered that residents of gated communities reported more occurrence of crime and at the same time felt less safe than the residents of open neighborhoods. The discourse of fear caused by crime has increased by the $2000 \mathrm{~s}$ and has been associated with distinct ethnic communities, as in Indians (Bunnell et al., 2010) and illegal migrants (Kassim, 1997).

It is usual for Malaysians to regards foreigners as threats in terms of social problems (Liow, 2004) and criminal activities (Kanapathy, 2006) to threaten in diluting the gene pool of Malaysians (Chin, 2008). Several studies proposed that the eagerness to improve safety and security. Some studies suggested that the desire to enhance safety and security (Xavier, 2008) alongside residents' fears of crime (Sakip et al., 2013) leads to the motivation to construct enclosed developments by middle-income groups in Selangor. Some researchers highlighted that among the common criminal violations in Malaysia include theft, robbery or burglary, murder, assault, and rape (Misnan et al., 2010; Hanif et al., 2012). Tan (2012) stated that approximately $90 \%$ of crime incidents in Malaysia consist of property crimes that mainly occur in housing areas.

Tan (2012) argued that over the past decades, crime rates in Malaysia have increased. The Malaysian Crime Prevention Foundation reported that the crime index has risen by almost 5\% between 2002 and 2003. According to the Malaysian Quality of Life Index (MQLI) (2008), the total number of reported crimes in Malaysia had worsened: $45 \%$ rise over the past four years from 156,315 cases in 2003 to 224,298 in 2007. The MQLI also reported that crimes per 1000 population have doubled from 3.8 to 7.1 between 1990 and 2000.

In the meantime, a spread in fear of crime was further boosted by the perception that the state could not effectively deal with the increased crime rates in the cities (Zumkehr and Andriesse, 2008). It has been argued by Mohit and Abdulla (2011) that insecurity contributes to the build of enclosures. Moreover, Hanif et al. (2012) recognize the role 
of the secondary factor in the enhancement of property values, the residents' desire for exclusive living, and privacy. Although, in general, the crime rates in Malaysia are relatively low, it seems that fear has outweighed the risk and, at the same time, become a compelling trigger for the development of enclosures (Tedong et al., 2017). Fear in this study is defined as the fear of crimes, fear of others, and fear of illegal foreigners.

Sakip et al., (2012) findings showed that residents of gated communities display a greater level of fear in crime than residents in non-gated housing areas. In addition, Hanif et al. (2012), in a detailed study of gated communities' safety and security features, found that although a security system helps reduce criminal offenses in the residential area, the residents' safety is not fully guaranteed. In other words, crime incidents may still occur in gated communities' development. For example, a study by Narayanasamy and Tahir (2010) found that crime had occurred in Johor Bahru due to the failure of the guards on duty to carry out their duties properly. They argued further that the desire of house buyers in Malaysia for safety and security features when opting for homes in gated communities is not as effective as one would presume.

The term "better quality of life" in the context of private neighborhood development in Malaysia would typically entail elements such as beautiful landscaping, good amenities, and facilities. Tan (2012) argued that it is typical in Malaysia for features such as beautiful landscaping and extensive greenery to have a substantive influence on the decision of residents to live in private neighborhood development. Interestingly Tan (2011) further examined how private neighborhood developments in which facilities and amenities are provided and coupled with good property maintenance practice tended to have higher prices.

\section{METHODOLOGY}

This study developed insights from a semi-structured in-depth interview with multiple key actors that included face-to-face interviews with guarded neighborhood residents, non-guarded neighborhood residents, and various stakeholders involved with guarded neighborhood development. In total, 29 respondents were involved with the semi-structured interviews. The qualitative interviews took between 60 to 90 minutes, which were usually recorded and transcribed for thematic analysis. The interviews were conducted to illustrate how they talked about the implications of guarded neighborhoods towards housing prices in Malaysia.

We also conducted document analysis by reviewing multiple government reports, media stories, and official statistics produced by relevant agencies related to guarded neighborhoods in Malaysia. Based on a qualitative inquiry guided by case studies analysis of guarded neighborhoods in Selangor state, this study will investigate the implications of guarded neighborhoods towards housing prices in Malaysia. Selangor state provides unique characteristics to study the guarded neighborhood phenomenon because it is among the most developed and urbanized state in Malaysia and has the highest concentration number of guarded neighborhoods in the country. Although systematic search strategies for locating guarded neighborhoods were employed, this study found limitations in evaluating communities since they are highly not accessible to outsiders because of physical boundaries and surveillance technologies. Therefore, this paper will examine how various actors interpret and discuss the relationship between housing prices and guarded neighborhood developments.

\section{RESIDENTS’ PERCEPTION ON GATED COMMUNITIES AND HOUSING PRICES}

Although security dictates the discourse to justify enclosing older residential areas, residents have acknowledged other gating motivations. The majority of residents of guarded neighborhood interviews viewed enclosure to bring forward property values as Khalid (2012) argued that Malaysian properties that come with robust security systems could fetch higher prices and had higher appreciation in value. For instance, one resident of a guarded neighborhood explained the property investment: "Even if my property price does not increase, I believe my house rentals will be high compared with open neighborhood properties."

Le Goix and Vesselinov (2012, p. 18) said that gated communities "more likely to profit from price bubble periods, and more likely to resist a sudden drop in value during downturns." This study revealed that in Selangor state, guarded neighborhoods could increase the property value due to the constant demand for security, lifestyle, and privacy. A member of the residents' association discussed this: "residents are prepared to pay a premium for maintenance fees so that the facilities or amenities - mostly public goods - could be maintained appropriately". One of the resident associations we interviewed also shared a similar opinion on the issue of property investment and said: 
"We collect maintenance fees from the residents so that we could maintain the neighbourhood area [...] the money will be used to run the guarded neighbourhood scheme from security guards to physical barriers [...] we hope by doing this our community will be more vibrant and indirectly will increase the property value of the community".

Residents of guarded neighborhoods felt that the property price would increase in the future due to the added security elements, better landscaping, and various other elements, as Xavier (2008) found that gated communities increased property values. One resident commented on this, "[...] from the economic side, I hope my house price in guarded neighborhood development will be increased in future, and this is why I am willing to participate in guarded neighborhood development". Another respondent also shared his view on this issue and contended that: "I intend to stay in guarded neighborhood development because I can feel and believe that my property value will increase significantly because we have a nice surrounding area."

The function of enclosures in both urban and suburban projects is no other than to enhance property values. The splendid lifestyle, accompanied by security guards, has facilitated a better quality of life, increasing property and rental values in private neighborhoods in Malaysia. All residents of guarded neighborhoods interviewed felt the features in guarded neighborhood development such as CCTV, barrier gates, security guards, better landscaping, and various other elements helped maintain or increase the property and rental value. However, it has to be pointed out that the increase in property price is only a presumption on the part of the residents. Realistically, there have been no official reports issued on this matter. When posed with the scenario of the property prices not increasing, one of the participants explained that;

"[... ]even if my property price do not increase, but I believe my rental will be high compared to non guarded neighbourhoods [...] but whatever happen I am confident I will not lose anything when I decided to participate in guarded neighbourhood development..."

Interviews revealed that the resident associations would endeavor to maintain and manage the neighborhood area to increase the liveability inside the guarded neighborhoods. In order to do that, the residents' association imposed maintenance fees so that the area inside the guarded neighborhood development can be maintained accordingly. One resident association talked about this:

"we collect maintenance fees from the residents so that we could maintain the neighborhood area [...] The money will be used to maintain the guarded neighborhood scheme from security guards to physical barriers [...] we hope by doing this our community will be more vibrant and indirectly will increase the property value of the community."

A further study was carried to substantiate the claim guarded neighborhood cause an increase in property value. The local authority was approached since residents' associations have to justify their reasons for the application to form a guarded neighborhood. In answering this question, one of the local authorities stated that:

"There is no strong evidence that can be linked between the price and the property inside the guarded neighborhood development [...] the property market price is not influenced by this kind of development but based on the current situation of the economic performance."

As such, it can be argued that in Malaysia, guarded neighborhoods attempt to create an aesthetically appealing environment as a reflection of a status symbol for the residents, with various packaging and branding to compete in the real estate market. Furthermore, the perception of buying property in a guarded neighborhood as a secured property investment has also become among the many reasons for the residents to choose to live in enclosed communities. However, one of the participants living in a guarded neighborhood development simply said;

"I am not so sure about the relationship between guarded neighborhoods and property prices. Perhaps you might want to consider other factors such as the current trend of property price according to the location and current economic performances".

Nevertheless, drawing from the empirical data, two conclusions can be summarised: some respondents agreed that in an enclosed community, the property price could increase in the future or at least maintained, and the rental price for properties in guarded neighborhoods is higher than those in guarded neighborhoods open neighborhoods. These findings are very significant because guarded neighborhoods could increase the property's 
value, caused by a perpetual increase in demand for security, lifestyle, and exclusive living over the years as similar observed in the American city such as California (Goix and Vesselinov, 2012).

\section{CONCLUSION}

This paper revealed that urban residents in Malaysia might appreciate property investment, privacy, and exclusive living when living in enclosures. As seen in other countries, the enclosure may discuss added property value (Le-Goix and Vesselinov, 2012; Ajibola et al., 2011) as Australia (Kenna, 2010), Barbados (Clement \& Grant, 2012), and Bulgaria (Stoyanov and Frantz, 2006). In Malaysia, gating may not have signaled the state's surrender on its monopoly on policing but rather mirror growing demands from both upper and middle classes in either urban and suburban areas to strengthen safety and enhance housing values. This study revealed that most respondents believed that their property values and the rental price would increase in the future. Therefore, by this point we argued that guarded neighborhood residents believed that their property values and rental price would increase in the future.

Security at the neighborhood level is briskly becoming not only an amenity but also a perceived necessity, which can be associated with maintaining property values and protect family members. Although most guarded neighborhood residents we interviewed prefer privacy and exclusive living, some believed that guarded neighborhood could protect their property value and investment. Residents' associations in Selangor state appear to be profoundly empowered and engaged in Malaysian cities. Responding to the appearance of new-gated communities promising security, the residents of older neighborhoods organized to close access to their streets. In doing so, they successfully exclude outsiders and enhance the perceived amenities and housing prices in their communities.

This paper also revealed that guarded neighborhoods take advantage of opportunities and differentiate products generated by gated communities to residents' associations charged with promoting neighborhood safety. Where residents desire safety and security, we found evidence that guarded neighborhood developments improved exclusivity and privacy, thus indirectly inducing higher housing prices in the area. In contexts like Malaysia, where housing prices are increasing every year, this study found that residents' associations responded to market needs by enclosing their community and increasing rental or property value. This study suggests that in Selangor state, guarded neighborhoods have significantly influenced the housing price in old neighborhood areas by providing more safety and security to the existing community.

\section{REFERENCES}

Atkinson, R., \& Blandy, S. (2006) Introduction: International perspectives on the new enclavism and the rise of gated communities. Housing Studies, 20(2), 177-186.

Ajibola, M., Oloke, O., \& Ogungbemi, A. (2011) Impacts of gated communities on residential property values: A comparison ONIPETESI estate and its neighbourhoods in IKEJA, Lagos State, Nigeria. Journal of Sustainable Development, 4(2), 72-729.

Blakely, E. J., \& Snyder, M. G. (1997) Fortress America: Gating communities in the United States. Washington Dc: Brooking Institution Press.

Bagaeen, S. \& Uduku, O. (2010) Gated communities: Social sustainability in contemporary and historical gated developments. Earthscan, London.

Blandy, S. (2006) Gated communities in England: Historical perspectives and current developments. GeoJournal, $66(1-2), 15-26$.

Blakely, E. J. (2007) Guest editor's introduction: Gated communities for a frayed and afraid world. Housing Policy Debate, 18(3), 475-480. Blakely, E. J., \& Snyder, M. G. (1997) Fortress America: Gating communities in the United States. Washington Dc: Brooking Institution Press.

Borsdorf, A., \& Hidalgo, R. (2010) From polarization to fragmentation. recent changes in Latin American urbanization. In P. Lindert \& O. Verkoren (Eds.), Decentralized Development in Latin America. Springer: Netherlands. 
Bunnell, T., Nagarajan, S., \& Willford, A. (2010) From the margins to centre stage: 'Indian' demonstration effects in Malaysia's political landscape. Urban Studies, 47(6), 1257-1278.

Caldeira, T. P. R. (2000) City of walls: Crime, segregation and citizenship in Sao Paulo. Berkeley and Los Angeles, California: University of California.

Candan, A. B., \& Kolluoglu, B. (2008) Emerging spaces of neoliberalism: A gated town and a public housing project in İstanbul. New Perspectives on Turkey, 39(n/a), 5-46.

Clement, R., \& Grant, J. L. (2012) Enclosing paradise: The design of gated communities in Barbados. Journal of Urban Design, 17(1), 43-60.

Çizmeci, F., \& Ercan, T. (2010) Changing perspectives on housing conceptions: privileged life style commitment. Paper presented at the Urban Dynamics \& Housing Change - Crossing into the 2nd Decade of the 3rd Millennium", 22nd (ENHR) International Housing Research Conference, Instanbul.

Chin, C. B. N. (2008) 'Diversification' and 'Privatisation': Securing insecurities in the receiving country of Malaysia. The Asia Pacific Journal of Anthropology, 9(4), 285-303.

Coy, M., \& Pohler, M. (2002) Gated communities in Latin American megacities: Case studies in Brazil and Argentina. Environment and Planning B-Planning \& Design, 29(3), 355-370.

Csizmady, A. (2011) Conflicts around gated communities. Paper presented at the Enhr Conference, Toulouse. Available at: http://www.enhr2011.com/sites/default/files/Paper_csizmady_WS23.pdf

Damstra, R. (2001) Don't Fence Us Out: The municipal power to ban gatedcommunities and the federal takings clause. Valparaiso University Law Review, 35(3), 525-560.

Dick, H. W., \& Rimmer, P. J. (1998) Beyond the third world city: the new urban geography of South-east Asia. Urban Studies, 35(12), 2303-2321.

Glasze, G. (2006) Segregation and seclusion: the case of compounds for western expatriates in Saudi Arabia. GeoJournal, 66(1-2), 83-88.

Grant, J., \& Mittelsteadt, L. (2004) Types of gated communities. Environment and Planning B-Planning \& Design, 31(6), 913-930.

Grant, J. (2006) Planning the good community: New urbanism in theory and practise. London and New York: Routledge.

Güzey, \& Özcan. (2010). Gated communities in Ankara, Turkey: Park renaissance residences as a reaction to fear of crime. Gazi University Journal of Science, 23(3), 365-375.

Gooblar, A. (2002) Outside the walls: Urban gated communities and their regulation within the british planning system. European Planning Studies, 10(3), 321-334.

Goold, B., Loader, I., \& Thumala, A. (2010). Consuming security?: Tools for a sociology of security consumption. Theoretical Criminology, 14(1), 3-30.

Hanif, N. R., Abdul Aziz. N. A. W. A., \& Tedong, P. A. (2012) Gated and guarded community in Malaysia: Role of the state and civil society. Paper presented at the Planning Law and Property Rights (PLPR), United Kingdom. http://www.plpr-association.org/index.php/papers-publications

Hishiyama, K. (2010) Uneasy society in Indonesia: with special attention to the gated community and CCTV in Bali. Procedia - Social and Behavioral Sciences, 2(1), 14-23.

Huong, L. T. T., \& Sajor, E. E. (2010) Privatization, democratic reforms, and micro-governance change in a transition economy: Condominium homeowner associations in Ho Chi Minh City, Vietnam. Cities, 27(1), 20-30. 
Kassim, A. (1997) Illegal alien labour in Malaysia: Its influx, utilization, and ramifications. Indonesia and the Malay World. 25(71), 50-81.

Kanapathy, V. (2006) Migrant workers in Malaysia: An overview. Paper presented at the East Asian Cooperation Framework for Migrant Labour, Kuala http://www.isis.org.my/index.php?option=com content\&view=article\&id=381:migrant-workers-inmalaysia-an-overview\&catid=92:papers \&Itemid $=55$

Khalid, K. (2012) Secure your home first, The New Strait Time. Available at: http://www.nst.com.my/red/secureyour-home-first-1.175104

LaCour-Little, M., \& Malpezzi, S. (2009) Gated streets and house prices. Journal of Housing Research, 18(1), 19-43.

Le Goix, R., \& Vesselinov, E. (2012) Gated communities and house prices: Suburban change in Southern California, 1980-2008. International Journal of Urban and Regional Research, (n/a), (n/a)

Le Goix, R. (2005) Gated communities: Sprawl and social segregation in Southern California. Housing Studies, 20(2), 323-343.

Le Goix, R., \& Webster, C. J. (2008) Gated communities. Geography Compass, 2(4), 1189-1214.

Leisch, H. (2002) Gated communities in Indonesia. Cities, 19(5), 341-350.

Levent, T. B., \& Gulumser, A. A. (2007) Gated communities in Istanbul: The new walls of the city. Paper presented at the Third Conference "Diversity in cities: Visible and invisible walls", UCL, London, UK. Available at: http://www.susdiv.org/uploadfiles/ed2007-051.pdf

Libertun De Duren, N. (2006) Planning à la Carte: The Location Patterns of Gated Communities around Buenos Aires in a Decentralized Planning Context. International Journal of Urban and Regional Research, 30(2), 308327.

Liow, J. C. (2004) Malaysia's approach to its illegal indonesian migrant labour problem: securitization, politics, or catharsis? Paper presented at the Idss-Ford Workshop On Non-Traditional Security In Asia, Singapore. Available at: http://www.rsis-ntsasia.org/resources/publications/researchpapers/migration/Joseph\%20Liow.pdf

Low, S. M. (2001) The edge and the center: Gated communities and the discourse of urban fear. American Anthropologist, 103(1), 45-58.

Low, S. (2003) Behind the gates: Life, security and the pursuit of happiness in fortress America. New York: Routledge.

Low, S. M. (2006) The erosion of public space and the public realm: Paranoia, surveillance and privatization in New York City. City \& Society, 18(1), 43-49.

Manzi, T., \& Smith-Bowers, B. (2005) Gated communities as club goods: Segregation or social cohesion? Housing Studies, 20(2), 345-359.

McKenzie, E. (2006) Emerging trends in state regulation of private communities in the U.S. GeoJournal, 66(1), 89102.

McKenzie, E. (2011) Beyond privatopia: Rethinking residential private government. Washington DC: The urban institute press.

Miao, P. (2003. Deserted streets in a jammed town: The gated community in chinese cities and its solution. Journal of Urban Design, 8(1), 45-66.

Misnan, S. H., Chan, E. H. W., \& Tang, B. S. (2010) The emerging patterns of guarded neighbourhood. The Hong 


Kong Polytechnic University. Available at:

http://www.bre.polyu.edu.hk/nius/pdf/Fencing $\% 20$ up $\% 20$ the $\% 20$ Communities $\% 20$ $\% 20$ Siti\%20 2009_.pdf

Mohit, M. A., \& Abdulla, A. (2011) Residents' crime and safety perceptions in gated and non-gated low middle income communities in Kuala Lumpur, Malaysia. Journal of Architecture, Planning and Construction Management, 1(1), 71-94.

Morange, M., Folio, F., Peyroux, E., \& Vivet, J. (2012) the spread of a transnational model: 'Gated Communities' in Three Southern African Cities (Cape Town, Maputo and Windhoek). International Journal of Urban and Regional Research, 36(5), 890-914.

Narayanasamy, J., \& Mohammad, M. T. S. H. (2011) Review of club theory in context of effective and efficient security management in malaysian gated and guarded communities. Paper presented at the International Conference on Social Science and Humanity, Singapore. http://www.ipedr.com/vol5/no2/110-H10265.pdf

Nelson, R. H. (2005) Private neighborhoods and the transformation of local government. United States of America: The Urban Institute.

Pow, C. P. (2007) Constructing a new private order: gated communities and the privatization of urban life in postreform Shanghai. Social \& Cultural Geography, 8(6), 813-833.

Pow, C.-P. (2009) Public intervention, private aspiration: Gated communities and the condominisation of housing landscapes in Singapore. Asia Pacific Viewpoint, 50(2), 215-227.

Pow, C. P. (2011) Living it up: Super-rich enclave and transnational elite urbanism in Singapore. Geoforum, 42(3), 382-393.

Raposo, R. (2006) Gated communities, commodification and aestheticization: The case of the Lisbon metropolitan area. GeoJournal, 66(1-2), 43-56.

Rosen, G., \& Grant, J. (2011) Reproducing difference: Gated communities in Canada and Israel. International Journal of Urban and Regional Research, 35(4), 778-793.

Sabatini, F., \& Salcedo, R. (2007) Gated communities and the poor in Santiago, Chile: Functional and symbolic integration in a context of aggressive capitalist colonization of lower-class areas. Housing Policy Debate, $18(3), 577-606$.

Sakip, S. R. M., Abdullah, A., \& Salleh, M. N. M. (2013) Fear of crime in residential areas. Asian Journal of Environment Behaviour Studies, 4(11), N/A.

Stake, R. E. (1995). The art of case study research. Thousand Oaks, CA: Sage.

Tahir, Z. b., \& Hussin, K. b. (2011) Security features in the gated community housing development. Paper presented at the International Conference On Management. Available at: http://www.internationalconference.com.my/proceeding/icm2011_proceeding/033 241_ICM2011_PG03 97 0404 GATED COMMUNITY.pdf

Tan, T.-H. (2011) Sustainability and housing provision in Malaysia. Journal of Strategic Innovation and Sustainability 7.1, 62-71.

Tan, T.-H. (2012) Meeting first-time buyers' housing needs and preferences in greater Kuala Lumpur. Cities, 29(6), 389-396.

Townshend, I. (2006) From public neighbourhoods to multi-tier private neighbourhoods: the evolving ecology of neighbourhood privatization in Calgary. GeoJournal, 66(1-2).

Tedong, P. A., Grant, L., \& Abd Aziz,W. N. A. W. (2014). The social and spatial implications of community action 
to enclose space: Guarded neighbourhoods in Selangor, Malaysia. Cities, 41(n/a) 30-37.

Tedong, P. A., Abd Aziz, W. N. A. W., Hanif, N. R., Zyed, Z. A., \& Abd Aziz, N. (2017). Planning implications of guarded neighborhoods in Malaysia. Community Development Journal, 52(4), 558-572.

Vesselinov, E. (2012) Segregation by design: Mechanisms of selection of latinos and whites into gated communities. Urban Affairs Review, 48(3), 417-454.

Vesselinov, E., Cazessus, M., \& Falk, W. (2007) Gated communities and spatial inequality. Journal of Urban Affairs, 29(2), 109-127.

Walks, R. A. (2006) Aestheticization and the cultural contradictions of neoliberal (sub)urbanism. Cultural Geographies, 13(3), 466-475.

Wu, F. (2010) Gated and packaged suburbia: Packaging and branding Chinese suburban residential development. Cities, 27(5), 385-396.

Xavier, G. (2008) Gated and guarded communities:Security concerns for elitist practice? Paper presented at the 5th Asian Law Institute Conference, Singapore. http://xa.yimg.com/kq/groups/22385556/248102641/name/Grace_Xavier_University_of_Malaya.pdf

Yin, R. (2011) Case study research: Design and methods (fourth edition). Los Angeles: SAGE Publications.

Yin, R. K. (2003) Case study research: Design and methods (3rd ed.). London: Sage Publications.

Zumkehr, H. J., \& Andriesse, E. (2008) Malaysia and South Korea: A decade after the Asian Financial Crisis. Chulalongkorn Journal of Economics, 20(1), 1-26. 